\title{
African American Male Library Administrators in Public and Academic Libraries
}

\section{Patricia Ball}

This study is designed to investigate the status of African American male library administrators who occupy administrative positions in academic and public libraries. African American male library administrators have distinctive demographic characteristics, educational backgrounds, professional characteristics, career patterns, and perceptions. A total of sixty-five African American male administrators were identified and mailed questionnaires. Race was identified in previous studies as a perceived barrier to professional advancement. The findings of this study corroborate earlier studies of African American professionals.

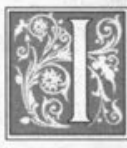

n many professions, White males dominate at the executive and management levels. This pattern is also prevalent in the executive suites of librarianship. Since the early 1930 s, studies relating to characteristics of library administrators have been conducted. Gender-based studies in library science conclude that men are the basic beneficiaries in the profession and have the most prestigious jobs; however, the results give no indication as to whether these characteristics apply to minority men, in particular, African American men.

Many studies examine the gender of library administrators and directors in both public and academic settings. The same conclusions are drawn from the majority of these studies. Basically, in librarianship, men have benefited with regard to salaries and managerial positions.
Previous studies indicate that women directors are found in greater numbers at smaller, private institutions. Male directors are usually younger than female directors. Male directors display a trend of high mobility, which is viewed as a vehicle to becoming directors at an earlier age than females become directors. Females, because of family responsibilities, are not as mobile. However, research shows that females have a better chance of becoming directors of libraries if they have been employed internally at the same library for a number of years. Investigations show that the salaries of women directors, on average, are much lower than those of their male counterparts. Statistics also point to the fact that White females have benefited the most from programs such as affirmative action.

For the most part, administrative positions in librarianship are distinguished

Patricia Ball, Ph.D., is a former Assistant Professor in the School of Library and Information Studies at Clark Atlanta University, Atlanta, Georgia; e-mail: patball@delphi.com. 
as positions of high status and power, with the director or chief of the library being at the apex. According to Stanley Eitzen, one of the characteristics of status that has an important influence on social identity, is the tendency for positions in

Basically, in librarianship, men have benefited with regard to salaries and managerial positions.

organizations to be differentially rewarded and esteemed. ${ }^{1}$

African American males, as well as other minorities, have both ascribed status and achieved status. Ascribed status is defined by Eitzen as a social position based on such factors as age, race, and family over which the individual has no control. Achieved status is a position in a social organization attained through personal effort. ${ }^{2}$ According to Eitzen, this is status inconsistency: A Black physician, for example, has high occupational status in American society but ranks low on the racial dimension of status. Such individuals are accepted and treated according to their high status by some, while others ignore the occupational dimension and consider only their race. ${ }^{3}$

The structure of social institutions plays an important part in determining African Americans' status. Their status results from race relations that have developed within social institutional structures. Beliefs, attitudes, and perceptions are products of the structure of society and its race relations, as well as determinants of those relations. ${ }^{4}$

\section{African American Male Librarians}

African American males have long been participants in the library profession. Although the literature does not provide a composite profile of Black male library administrators, it does chronicle the path of African American males into executive suites of librarianship. Librarians such as Daniel Alexander Payne Murray, S.W. Stark, Daniel A.P. Murray, George Wash- ington Forbes, Edward Christopher Williams, J. Arthur Jackson, Richard T. Greener, and Thomas Fountain Blue are some of the historical ground breakers for African American males in library administration. Black men have risen to positions of accomplishment in the library profession despite enormous social obstacles.

More recently in the twentieth century, the author finds numerous African American males who have made significant contributions to librarianship. In 1932, Arthur A. Schomburg was named curator of the New York Public Library research collection, which later was named for him. Arna Bontemps was appointed in 1943 as university librarian of Fisk University. He was the first African American to serve in this position. In 1968 E. J. Josey became chief of the Bureau of Academic and Research Libraries of the New York State Education Department and the first elected Black male president of ALA. Hardy Franklin, director of the District of Columbia Public Library, was elected president of ALA for the 19931994 term, becoming the second African American male to be elected to that position. ${ }^{5}$ The literature documents event after event of African American males who crossed over into the executive suites of librarianship.

\section{Research Design}

Using descriptive, analytical, and survey methods, the author conducted this study to ascertain the status of African American male administrators in academic and public libraries. To identify the population for the study, The American Library Directory, The Directory of Ethnic Professionals in Library and Information Science, and The Black Caucus of the American Library Association Membership Directory were used. . $^{6-10}$ The author identified sixty-five African American male administrators for the study, and verified their current positions and places of employment by telephone. 
In an effort to gather information on the status, demographic characteristics, and perceptions of African American male library administrators, the survey instrument addressed three major questions: 1) What characteristics describe African American male administrators in the profession? 2) What is the status of African American male administrators in the profession? and 3) Are there perceptions of discrimination among African American male administrators in the profession?

\section{Demographic Characteristics}

Sixty respondents returned their questionnaires, for a total return rate of 92.3 percent. The majority of African American male library administrators (45.5\%) responding to this survey were born in southern states. The majority $(44.4 \%)$ of African American male library administrators are between forty-six and fifty-five years of age, married (53.9\%), and have no children $(42.3 \%)$. However, it is interesting to note that none of the respondents was under twenty-five years of age or over sixty-six years of age. The average number of children for the group as a whole is 1.4 , with the total number of children ranging from one to five.

African American male library administrators are basically from middle-class to lower-middle-class backgrounds. A total of 31.5 percent of respondents categorized their mother's occupation as "homemaker." The majority of the respondents' fathers $(48.1 \%)$ were employed in a blue-collar profession. "Service worker" was listed as the second largest category for mothers (18.5\%). "Other" is the way many respondents described their fathers' professions (25.5\%).

The majority of African American male library administrators participating in the survey attended predominantly Black undergraduate colleges $(63.6 \%)$ in a southern state $(40 \%)$. Morehouse College $(36.3 \%)$ was the most frequently cited un- dergraduate institution. Respondents attending non-Black institutions comprised 36.4 percent of responses to this item on the survey. Social sciences $(25.5 \%)$ was the field that the majority of respondents listed most frequently as their undergraduate major. Fewer of the respondents majored in law $(1.8 \%)$ or in a physical science (1.5\%).

\section{Career Patterns}

For the majority of African American male library administrators in this survey, librarianship was not the first career choice $(75.9 \%)$. Librarianship was the first career choice for only 24.1 percent of respondents. Teaching was the career of choice for the majority of respondents (16.4\%), followed by medicine (12\%). Respondents participating in this study attended a variety of library schools. Twenty-four different library schools were listed. However, the most commonly listed library school was Clark Atlanta University, with 30.9 percent of respondents having received their master of library science there. The Universities of Pittsburgh and Illinois were the library schools listed most frequently after Clark Atlanta. The decision to attend library school was made immediately by 44.4 percent of the respondents. Only one respondent did not go to library school.

Administrators responding to the study were highly educated. A large percentage $(41.8 \%)$ of the respondents pos-

\section{... the most commonly listed library school was Clark Atlanta University, with $\mathbf{3 0 . 9}$ percent of respondents having received their master of library science there.}

sessed earned doctoral degrees. A larger percentage $(45.5 \%)$ had earned a master's degree and three $(9.1 \%)$ have two master's degrees. Only two of the respondents $(3.6 \%)$ stated that their highest degree was a baccalaureate degree. Thirteen $(23.6 \%)$ of the respondents returning their 
questionnaires indicated that they had advanced degrees in other fields.

The salary for the majority of respondents fell into two categories. Most respondents listed their salaries as either $\$ 35,001-\$ 40,000$ or over $\$ 65,000$ (20.4\%). The salary range listed most often after the previously mentioned two ranges, was that of $\$ 40,001-\$ 45,000$, with 14.8 percent of the respondents listing this category. This category was followed by $\$ 45,001-\$ 50,000(13 \%)$ and $\$ 55,001-$ $\$ 60,000$ (13\%).

Based on this study, African American male library administrators have remained in their current positions for an average of 8.6 years (the median is five years, and the mode is one year). Over half of the respondents (twenty-nine total) had been in their present positions for one to five years $(53.8 \%)$. At least seven (13.1\%) respondents said that they were in their current positions for six to ten years. Only one (1.9 percent) respondent marked the twenty-six-to-thirty-year category.

African American males became administrators at an average age of $\mathbf{2 9 . 8}$ years. The mode was twenty-eight years of age and the median was twenty-nine years of age. The majority of respondents, twenty-five $(46.3 \%)$ in all, responded that they first became administrators between the ages of twenty-six and thirty. The majority of African American male library administrators $(72.3 \%$ ) responding to this survey held other administrative positions in the profession. Only thirteen (25.9\%) had not held other library administrative positions. Prior to their current positions, study participants had held, on average, 2.5 administrative positions.

Respondents who had occupied other administrative positions in librarianship had been in a variety of positions. Some had occupied more than one administrative position. Others had worked at several of the same types of positions; for example, one respondent had previously occupied two positions as dean of the li- brary, and one as head of an undergraduate library, associate director, and director of library services. Positions held by these administrators also ranged over a number of years, with the least amount of time at a previous position being one year and the most time fifteen years. Respondents participating in this study had held an average of 2.5 administrative positions in librarianship before being appointed to their present positions.

Many African American males in the profession had occupied other top positions in other fields. Of the respondents in this study, twelve or 22.2 percent were in administrative positions in other professional fields. A total of fifty-four respondents answered this question on the questionnaire. The majority of respondents, forty-two total $(77.7 \%)$, had not worked in administrative positions in other fields.

Librarians have most influenced African American males to pursue librarianship as a career. Fifty-one respondents responded to this item on the instrument. Of those responding, eleven listed "selfinitiative" in response to this question. Respondents listing "other" to this question totaled 15.7 percent. "Friends" $(9.8 \%)$, "relatives" (3.9\%), and "teachers" $(7.8 \%)$ were listed as also having influenced career choices. The majority of respondents, thirty-six total $(65.5 \%)$, had been employed in libraries while attending college. Of the respondents who had worked in a library while attending college, twenty-five ( $46.3 \%)$, had been employed in an academic library. A smaller portion of respondents, seven (13\%), had worked in a public library, and three (5.5\%) had worked in a special library while attending college. None of the respondents had been employed in a school library while in college.

African American males had high career expectations. The questionnaire asked respondents attending library school to describe the position they hoped to obtain. The responses were divided 
into two categories: administrative and staff. A total of fifty respondents answered this question on the questionnaire. Of those, twenty-nine $(58 \%)$ responded that their goal was to obtain an administrative position, while twentyone $(42 \%)$ responded that their goal was to obtain a staff position. The majority of the respondents, forty-three $(79.6 \%)$, received some type of financial assistance while attending library school. "Enjoyable" and "a noble profession" are the words African American males used in describing their love for librarianship. "It is a field that empowers people through providing information," said one respondent. Another stated, "I love it!" Item 24 on the questionnaire asked respondents, "If you were to make the initial career decision again, would you choose librarianship?" Over half of the respondents, forty-five $(81.8 \%)$, said they would choose librarianship as their first career choice. Only six $(10.9 \%)$ of the respondents replied no.

\section{African American Male Library Administrators' Status}

What is the status of African American male library administrators in the profession? Despite the low number of African American males in the profession, those in administrative positions are considered to be in top administrative positions. The majority of respondents participating in this study are directors of libraries. Over half of the respondents, twenty-eight $(51.9 \%)$, are in this position. The second largest category was that of "other." Fourteen (16.7 percent) administrators responded to this category. There were two respondents who are presently in the position of associate director $(3.7 \%)$, one assistant director (1.9\%) and nine branch heads $(16.7 \%)$. The fourteen respondents who categorized their positions as "other" listed their current titles as the following: head librarian and assistant director of Learning Resource Center; head librarian; branch manager; executive di- rector; regional librarian; administrative services librarian; deputy director; state librarian; dean of libraries; area administrator; assistant dean of instructional resources; dean; assistant deputy director; and director and professor of law.

African American male library administrators were asked to rate their perceptions of opportunities in the profession for African American males. Space was provided on the questionnaire for respondents to make additional comments. A total of twenty-five $(45.45 \%)$ of the re-

... although some respondents rated
opportunities ... as being "good"
for African American males, their
comments underscored racial
prejudice as a problem in the
profession.

spondents made additional comments. Most African American males perceived opportunities to be "very good" or "fair." The total number of respondents who rated opportunities as "fair" or "very good" was sixteen for each category (29.1\%). An interesting observation is that although some respondents rated opportunities in the profession as being good for African American males, their comments underscored racial prejudice as a problem in the profession. For example, one respondent who described opportunities for African American males as "good" commented: "Related to communities with significant percentage of minority population, racism will continue to restrict opportunities." Only eight $(14.5 \%)$ of the fifty-five respondents described opportunities as "excellent" for African American males. Other respondents listed opportunities in the profession as "very good" (29.1\%); "fair" (29.1\%); "good" (21.8\%); or "poor" (5.5\%).

Comments made by the majority of respondents centered on four issues in librarianship. The first issue involved sexism. Respondents made several comments that described the sentiments of 
this minority in the profession. One respondent said: "Opportunities always exist for outstanding professionals, regardless of sex; although males often rise disproportionately to administrative positions." A similar comment was made by another respondent who indicated that, "In the current job market, African American males must compete with well-prepared, highly competent black and white females for scarce administrative professional positions. ..."

A second issue addressed by many of the respondents involved racial prejudice and discrimination in the profession. To better illustrate what the general consensus is pertaining to this issue in librarianship, one of the respondents summed it up by stating: "African Americans still face institutional racism toward blacks in upper management in some areas of librarianship." A similar comment by a respondent also reflects this sentiment: "Racism and prejudice still exist but are much more subtle now." One respondent said, "In general, this profession gives a lot of lip service about affirmative action and equal opportunity, but ... for African American males there are still many barriers to advancement, especially rapid advancement."

A third issue that surfaced from the comments made by respondents centered on limited opportunities within the profession for African American males. This was expressed by one respondent when he said, "Advancement up the ladder is too slow. African American males are not provided the opportunities offered to their non-Black colleagues, i.e., Librarian of Congress, Librarian-Kennedy Center, Pentagon Librarian, etc." This sentiment was expressed differently by another respondent who said, "They seem to be nonexistent." Along these same lines, another said, "I would argue that opportunities are limited," while another respondent commented that "Within the right environment there are a number of opportunities."
A fourth issue that surfaced from the respondents' comments involved recruitment and retention. Several respondents expressed their concern about the recruitment and retention of qualified African American males within the profession. One respondent stated, "Now that HEA Title II B Fellowships are funded again, recruitment of minorities, especially of black males could and should be intensified." Another respondent discussed the lack of African American males in librarianship, saying that because of "the fact that not many African American males exist in the profession period, those that are seeking advancement face racial attitudes, location problems and other deterrents in seeking opportunities." One respondent stated, "... I am the only male Black Branch Manager in my Library System." Such comments seem to illustrate the need for better recruitment methods and retention devices.

African American males possess varied skills, and their opinions about what factors have influenced their professional advancement are even more varied. Section four of the instrument asked African American male library administrators to place a value on identified factors in regard to their importance to professional advancement. The ratings reflect that numerous factors have affected professional growth for respondents to this survey. This fact is also reflected in many of the comments made by African American males. For instance, one respondent said, "All these skills are important and affect the performance level of all administrators including African American males."

The scale for this section of the questionnaire was 5) very important, 4) important, 3) moderately important, 2) of little importance, and 1) not at all important. The questionnaire first asked respondents to rate several factors: communication skills, organizational skills, having political connections, willingness to relocate geographically, having someone as a mentor, having a strong academic back- 
ground, having problem-solving abilities, possessing a varied background of experiences, having a willingness to take risks; and having knowledge of the dynamics of library services. Space was provided at the end of this section for respondents who might want to make comments. A total of twelve respondents made comments in regard to factors that have influenced professional growth (see table 1). The highestrated factor is communication skills. Respondents' average response to this factor on a scale of one to five was 4.69 . The importance of this factor to professional growth among this minority in the profession is reflected in this comment by one of the study's participants: "All other skills hinge on my ability to write and speak effectively...."

The second most important factor was organizational skills. The average rating for this factor was 4.49 . Table 2 provides an illustration of the ranking of these factors by participants in descending order, by mean.

The lowest-rated factor for the group is political connections. Its average for the group was 2.40. Although rated low, it sparked the following comment by a respondent: "An African American male must be aware that he has to be more astute, more competitive, and more politically aware than his white colleague." A similar comment in regard to risk taking

\section{TABLE 1}

to Professional Advancement

\begin{tabular}{|c|c|c|c|c|c|c|c|}
\hline Factors & $\begin{array}{l}\mathbf{N} \\
\%\end{array}$ & $\mathrm{NI}^{1}$ & LI & MI & I & VI & Mean \\
\hline $\begin{array}{l}\text { a) Communication } \\
\text { Skills }\end{array}$ & $\begin{array}{l}\mathbf{N} \\
\%\end{array}$ & $\begin{array}{l}\mathbf{0} \\
\mathbf{0}\end{array}$ & $\begin{array}{l}\mathbf{0} \\
\mathbf{0}\end{array}$ & $\begin{array}{l}0 \\
0\end{array}$ & $\begin{array}{l}17 \\
30.9\end{array}$ & $\begin{array}{l}38 \\
69.1\end{array}$ & 4.69 \\
\hline $\begin{array}{l}\text { b) Organizational } \\
\text { Skills }\end{array}$ & $\begin{array}{l}\mathbf{N} \\
\%\end{array}$ & $\begin{array}{l}\mathbf{0} \\
\mathbf{0}\end{array}$ & $\begin{array}{l}1 \\
1.8\end{array}$ & $\begin{array}{l}3 \\
5.5\end{array}$ & $\begin{array}{l}19 \\
34.5\end{array}$ & $\begin{array}{l}32 \\
58.2\end{array}$ & 4.49 \\
\hline $\begin{array}{l}\text { g) Problem } \\
\text { Solving }\end{array}$ & $\begin{array}{l}\mathbf{N} \\
\%\end{array}$ & $\begin{array}{l}0 \\
0\end{array}$ & $\begin{array}{l}\mathbf{0} \\
\mathbf{0}\end{array}$ & $\stackrel{6}{10.9}$ & $\begin{array}{l}24 \\
43.6\end{array}$ & $\begin{array}{l}25 \\
45.5\end{array}$ & 4.35 \\
\hline $\begin{array}{l}\text { f) Academic } \\
\text { Background }\end{array}$ & $\begin{array}{l}N \\
\%\end{array}$ & $\begin{array}{l}\mathbf{0} \\
\mathbf{0}\end{array}$ & $\begin{array}{l}\mathbf{0} \\
\mathbf{0}\end{array}$ & $\begin{array}{l}10 \\
18.2\end{array}$ & $\begin{array}{l}25 \\
45.5\end{array}$ & $\begin{array}{l}20 \\
36.4\end{array}$ & 4.18 \\
\hline $\begin{array}{l}\text { h) Varied } \\
\text { Experiences }\end{array}$ & $\begin{array}{l}\mathbf{N} \\
\%\end{array}$ & $\begin{array}{l}1 \\
1.8\end{array}$ & $\begin{array}{l}1 \\
1.8\end{array}$ & $\begin{array}{l}8 \\
14.5\end{array}$ & $\begin{array}{l}26 \\
47.3\end{array}$ & $\begin{array}{l}19 \\
34.5\end{array}$ & 4.11 \\
\hline i) Take Risks & $\begin{array}{l}\mathbf{N} \\
\%\end{array}$ & $\begin{array}{l}4 \\
7.3\end{array}$ & $\begin{array}{l}3 \\
5.5\end{array}$ & $\begin{array}{l}14 \\
25.5\end{array}$ & $\begin{array}{l}20 \\
36.4\end{array}$ & $\begin{array}{l}14 \\
25.5\end{array}$ & 3.67 \\
\hline d) Relocate & $\begin{array}{l}\mathbf{N} \\
\%\end{array}$ & $\begin{array}{l}10 \\
18.2\end{array}$ & $\begin{array}{l}3 \\
5.5\end{array}$ & $\begin{array}{l}5 \\
9.1\end{array}$ & $\begin{array}{l}18 \\
32.7\end{array}$ & $\begin{array}{l}19 \\
34.5\end{array}$ & 3.60 \\
\hline e) Mentor & $\begin{array}{l}\mathbf{N} \\
\%\end{array}$ & $\begin{array}{c}6 \\
10.9\end{array}$ & $\begin{array}{l}4 \\
7.3\end{array}$ & $\begin{array}{l}24 \\
43.6\end{array}$ & $\begin{array}{l}10 \\
18.2\end{array}$ & $\begin{array}{l}11 \\
20.0\end{array}$ & 3.29 \\
\hline $\begin{array}{l}\text { c) Political } \\
\text { Connections }\end{array}$ & $\begin{array}{l}\mathbf{N} \\
\%\end{array}$ & $\begin{array}{l}13 \\
23.63\end{array}$ & $\begin{array}{l}19 \\
34.55\end{array}$ & $\begin{array}{c}13 \\
23.63\end{array}$ & $\begin{array}{l}8 \\
14.54\end{array}$ & $\begin{array}{c}2 \\
3.64\end{array}$ & 2.40 \\
\hline
\end{tabular}

was made by a respondent who said, "Because of the changing nature of the field, abilities such as risk-taking; adaptability and problem-solving will overcome other barriers (racism, sexism and elitism)."

The final section of the questionnaire, section five, asked respondents to rate factors that may be a problem for them in their position as African American male library administrators. Respondents rated a total of seven factors: 1) having your credibility as an administrator challenged because of your race, 2) lacking African American male librarians to serve as role models, 3 ) being stereotyped because of your race, 4) competing in selection processes for available positions, 5) being accepted by others as a competent 


\section{TABLE 2}

Factors in Descending Order by Mean

Factors Related to Advancement

Problem Factors

Communication Skills

Organizational Skills

Problem-Solving Abilities

Varied Academic Background

Varied Experiences

Take Risks

Relocate geographically

Having Someone as a Mentor

Political Connections
Selection Process

Old Boy Network

Stereotyped Because of Race

Credibility Being Challenged

Lack of Role Models

Competent Administrator

Family Responsibilities

\section{TABLE 3}

Problem Factors for African American Male Administrators

\begin{tabular}{|c|c|c|c|c|c|c|c|}
\hline Factors & $\begin{array}{l}\mathbf{N} \\
\%\end{array}$ & $\mathbf{N P}^{1}$ & SP & MP & $\mathbf{P}$ & SRP & Mean \\
\hline $\begin{array}{l}\text { d) Selection } \\
\text { Process }\end{array}$ & $\begin{array}{l}\mathbf{N} \\
\%\end{array}$ & $\begin{array}{l}10 \\
18.9\end{array}$ & $\begin{array}{l}11 \\
20.8\end{array}$ & $\begin{array}{l}16 \\
30.2\end{array}$ & $\begin{array}{c}9 \\
17.0\end{array}$ & $\begin{array}{c}7 \\
13.2\end{array}$ & 2.85 \\
\hline $\begin{array}{l}\text { f) Old Boy } \\
\text { Network }\end{array}$ & $\begin{array}{l}\mathbf{N} \\
\%\end{array}$ & $\begin{array}{l}16 \\
29.1\end{array}$ & $\begin{array}{c}9 \\
16.4\end{array}$ & $\begin{array}{l}13 \\
23.6\end{array}$ & $\begin{array}{l}11 \\
20.0\end{array}$ & $\begin{array}{l}6 \\
10.9\end{array}$ & 2.67 \\
\hline $\begin{array}{l}\text { c) Stereotyped } \\
\text { Race }\end{array}$ & $\begin{array}{l}\mathbf{N} \\
\%\end{array}$ & $\begin{array}{l}13 \\
24.1\end{array}$ & $\begin{array}{l}14 \\
25.9\end{array}$ & $\begin{array}{l}16 \\
29.6\end{array}$ & $\begin{array}{l}10 \\
18.5\end{array}$ & $\begin{array}{l}1 \\
1.8\end{array}$ & 2.48 \\
\hline a) Credibility & $\begin{array}{l}\mathbf{N} \\
\%\end{array}$ & $\begin{array}{l}10 \\
18.5\end{array}$ & $\begin{array}{l}20 \\
37.0\end{array}$ & $\begin{array}{l}17 \\
31.5\end{array}$ & $\begin{array}{c}7 \\
13.0\end{array}$ & $\begin{array}{l}0 \\
0\end{array}$ & 2.39 \\
\hline $\begin{array}{l}\text { b) Lack of } \\
\text { Role Models }\end{array}$ & $\begin{array}{l}\mathbf{N} \\
\%\end{array}$ & $\begin{array}{l}19 \\
34.5\end{array}$ & $\begin{array}{l}18 \\
32.7\end{array}$ & $\begin{array}{l}11 \\
20.0\end{array}$ & $\begin{array}{l}4 \\
7.3\end{array}$ & $\begin{array}{l}3 \\
5.5\end{array}$ & 2.16 \\
\hline $\begin{array}{l}\text { e) Competent } \\
\text { Administrator }\end{array}$ & $\begin{array}{l}\mathbf{N} \\
\%\end{array}$ & $\begin{array}{l}16 \\
29.1\end{array}$ & $\begin{array}{l}20 \\
36.4\end{array}$ & $\begin{array}{l}14 \\
25.5\end{array}$ & $\begin{array}{l}4 \\
7.3\end{array}$ & $\begin{array}{l}1 \\
1.8\end{array}$ & 2.16 \\
\hline $\begin{array}{l}\text { g) Family } \\
\text { Responsibilities }\end{array}$ & $\begin{array}{l}\mathbf{N} \\
\%\end{array}$ & $\begin{array}{l}40 \\
74.1\end{array}$ & $\begin{array}{l}6 \\
11.1\end{array}$ & $\begin{array}{l}8 \\
14.8\end{array}$ & $\begin{array}{l}\mathbf{0} \\
\mathbf{0}\end{array}$ & $\begin{array}{l}\mathbf{0} \\
\mathbf{0}\end{array}$ & 1.41 \\
\hline
\end{tabular}


administrator, 6) being accepted into the "old boy network," and, finally, 7) having family responsibilities. Space was provided for additional comments. A total of ten respondents made comments (see table 3). The data for this section of the questionnaire are divided into two sections. The first part presents the results of the total population, while the second section divides the responses in accordance with which type of library currently employs the respondents. Three library categories were created: Historically Black/Academic Institutions, NonBlack/Academic Institutions, and Public and Other Institutions (state libraries, etc.). The overall responses to these factors are reflected in table 4 in descending order.

Study participants rated the selection process for available positions as a factor causing the most problems for them. Problem as defined by the Merriam-Webster Dictionary is "a source of perplexity or vexation." "The average for this factor for the overall group was 2.85 . However, this factor was a problem to some degree for 81.2 percent of respondents. Only 18.9 percent of those responding rated this factor as "not a problem." This factor was followed in its rating by acceptance into the "old boy network." It was rated by 70.9 percent of respondents as posing some degree of problem. The factor that was rated the least problematic for this group involved family responsibilities. The average for this factor was 1.41, and it was not a problem for 74.1 percent of the study population.

Most African American male library administrators are employed by public libraries. A total of 27.3 percent are employed by historically Black academic institutions. This may account for the lowest overall mean of the factors that may be problems for this group. This fact is also reflected in comments made by several of the respondents. For example, one said, "My responses might be somewhat different if I did not work at a black insti- tution. Although I am confident that I would succeed anywhere." Another respondent made a similar comment, saying, "I have worked as a library administrator for the most part at historically Black universities." Of the remaining respondents; 29.1 percent were employed in non-Black academic institutions; 40 percent in public; and 3.6 percent in other types of institutions.

When responses to problem factors are differentiated by type of institution, the average for administrators employed at the different types of institutions is significantly different. Overall, with the exception of two factors, the average for those administrators at historically Black academic institutions is lower than at other types of institutions.

For most African American males employed by non-Black academic institutions (for the purposes of this study, a nonBlack academic institution is defined as a predominantly White academic institution) or at public and other institutions, having your credibility as an administrator challenged because of race is a problem to some degree for most of the respondents. For all of the respondents at non-Black academic institutions this factor presents a problem to some degree. For 60 percent it is a small problem. For 31.25 percent of respondents it is a moderate problem, and for 12.5 percent it is a problem. For respondents employed at public and other institutions this factor is to some degree a problem for 82.1 percent of the study population. It is a small or moderate problem for 30.43 percent for each category and a problem for 21.74 percent of respondents at public and other institutions.

Lack of African American male librarians to serve as role models is the only category where the average is higher for historically Black academic institutions than for non-Black academic institutions. This factor is more of a problem for administrators serving in public and other institutions than for those in academic 
TABLE 4

Percentage of Responses to Factors by Type of Institution Presently Employed

Factors

$\mathbf{N}$

NP SP

a) Credibility

His. Black

Non-Black

Public

$\begin{array}{lcl}15 & 40 & 26.6 \\ 16 & 0 & 60 \\ 23 & 17.39 & 30.43\end{array}$

33.33

$\begin{array}{lll}31.25 & 12.5 & 0\end{array}$

1.93

$\begin{array}{lll}30.43 & 21.74 \quad 0\end{array}$

2.56

and Other

b) Lack of Role

Models

His. Black

Non-Black

Public

$15 \quad 40$

40

$\begin{array}{ll}33.33 & 13.33\end{array}$

$\begin{array}{lll}43.75 & 25 & 25\end{array}$

$\begin{array}{ll}6.7 & 6.7\end{array}$

2.1

and Other

24

\begin{tabular}{ll|l}
25 & 37.5 & 20.83
\end{tabular}

6.25

0

1.93

2.37

c) Stereotyped Race

His. Black 14

$\begin{array}{ll}\text { His. Black } & 14 \\ \text { Non-Black } & 16\end{array}$

$\begin{array}{lllll}42.85 & 21.42 & 14.28 & 21.42 & 0\end{array}$

2.15

Public

24

31.2525

$\begin{array}{lll}31.25 & 12.5 & 0\end{array}$

2.25

and Other

d) Selection Process

His. Black 15

Non-Black 15

$\begin{array}{ll}8.33 & 29.17\end{array}$

37.5

$20.83 \quad 4.17$

2.83

Public

$\begin{array}{lll}26.7 & 33.33 & 20\end{array}$

6.6

13.33

2.47

13.33 20

40

20

6.67

2.87

and Other

e) Competent

Administrator

\begin{tabular}{llllllll} 
His. Black & 15 & 33.33 & 40 & 6.67 & 20 & 0 & 2.13 \\
Non-Black & 16 & 12.1 & 62.5 & 25 & 0 & 0 & 2.13 \\
$\begin{array}{l}\text { Public } \\
\text { and Other }\end{array}$ & 24 & 37.5 & 16.67 & 37.5 & 4.17 & 4.17 & 2.21 \\
\hline
\end{tabular}

f) Old Boy

Network

His. Black

22

$46.67 \quad 20$

$\begin{array}{llll}6.67 & 26.67 & 0\end{array}$

2.13

Non-Black

12.5

18.75

$\begin{array}{lll}18.75 & 31.25 & 18.75\end{array}$

3.25

Public

24

29.17

$12.5 \quad 37.5$

$8.73 \quad 12.5$

2.62

g) Family

Responsibilities

$\begin{array}{llllllll}\text { His. Black } & 15 & 66.67 & 26.67 & 6.67 & 0 & 0 & 1.4 \\ \text { Non-Black } & 16 & 75 & 0 & 25 & 0 & 0 & 1.5 \\ \text { Public } & 23 & 78.26 & 8.69 & 13.04 & 0 & 0 & 1.29 \\ \text { and Other } & & & & & & & \end{array}$

Based on total number of responses to each factor.

$\mathrm{NP}=$ Not a Problem, SP=Small Problem, MP=Moderate Problem, $\mathrm{P}=$ Problem, SP=Serious Problem. His. Black=Historically

Black Academic Institutions, Non-Black=Non-Black Academic Institutions, Public and Other=Public Libraries and Other.

institutions. In response to this factor, one respondent made the following statement: "...I worked with a long-time male administrator on some professional mat- ters (we worked in different libraries). It's amazing how much you can learn just being in the vicinity. Unfortunately, I have not experienced much in the way of Afri- 
can American male or female role models while on the job. Therefore, for the most part, I have not found a zone of comfort in personal interactions with colleagues." This reflects the need for recruitment and retention of qualified African American males in the profession.

Respondents who marked the category of "Public and Other" have more of a problem with being stereotyped because of race than respondents at non-Black academic institutions and those at historically Black institutions. The mean for respondents at historically Black institutions is lower than the other two categories. Generally, the character of comments made by respondents suggests that race is perceived as a problem for African American male administrators. For example, one respondent said: "All too often black males are regarded as having only a limited aspiration level in terms of higher administration. At the Deputy and Director level they become viewed as unwanted competition by females and white male administrators." Another respondent made a comment that helps to illustrate these sentiments further, "Subtle and even unconscious racism is still widespread in the profession. It has to be confronted and exposed at every opportunity, but can never be used as an excuse for not accomplishing one's goals."

The selection process for available positions is little more than a moderate problem for administrators employed by public and other institutions. This factor's average for administrators at public and other institutions was higher than for the other two categories. The mean for this factor for administrators employed at historically Black institutions is the lowest, 2.47. In relation to this problem, one respondent commented, "In the current job market, African American males must compete with well-prepared, highly competent black and white females for scarce administrative positions. This is also true for non-administrative positions...."
The mean (2.21\%) for African American males at public and other institutions for the problem factor of being accepted as a competent administrator was the highest of the three types of institutions ( $2.13 \%$ for both historically Black institutions and non-Black institutions). The extent of the impact of this factor is described by one respondent as follows: "Being accepted as a competent administrator is not a problem. The problem

\section{Lack of African American male librarians to serve as role models is the only category where the average is higher for historically Black academic institutions than for non- Black academic institutions.}

when you are extremely competent is 'you expect too much,' 'you are hard to work for,' 'your management style is intimidating,' etc. These are ways of saying 'you are good and we can't let you be perfect.' Racism is a factor and you have to constantly be aware of this."

Acceptance into the "old boy network" for administrators at non-Black institutions had the greatest mean for all factors. This factor averaged 3.25 for this group. It poses more of a special problem in librarianship. This is reflected in one comment made by a respondent: "In the library profession instead of the 'old boy' network it's the 'old gal' network. Fortunately, [sic] my supervisors are veterans and tested; our focus is to provide library services where few black and white librarians dare or want to go. Politics beyond providing services to children is the area we want to be part of. We want more for them."

Administrators at historically Black academic institutions have less of a problem with this factor than their other peer colleagues. The fact that this is a serious problem is also reflected in this comment made by one participant: "Being director of my hometown public library has 
helped to overcome some of the 'barriers;' i.e., acceptance into the 'old boy network' but I still feel the need to be 'twice as good.'"

The factor dealing with family responsibilities causes the fewest problems for this minority. For administrators at all types of institutions this factor ranged between "not a problem" and a "small problem." The lowest mean was for administrators serving currently at public or other institutions. Overall, the two greatest problems for administrators in the profession are acceptance into the old boy network and the selection process for available positions.

\section{Comparison of Factors}

When looking closer at factors rated by respondents as related to professional advancement and factors identified as problems by respondents, an interesting phenomenon is observed. There is an inverse relationship between the two groups of factors. Of relevance to these findings is a body of research in social psychology on how people explain a social phenomenon. In A Common Destiny: Blacks and American Society, David Jaynes and Robin Williams explain this phenomenon in the following way:

Attribution theory focuses primarily on how people develop explanatory accounts of interpersonal behavior. The two major types of causes are external, such as an environmental constraint or pressure to behave in a particular way, and internal, indicative of the underlying dispositions of the individual. Of course, many behaviors involve combinations of the two kinds of causes. The way in which a phenomenon is explained largely determines the meaning it has for a person. An outcome lacking a systematic, controllable cause differs from an outcome for which a clear social process or individual action can be pinpointed as the cause. Furthermore, outcomes rooted in a social force have different implications for ameliorative efforts than those rooted in a personal intention. The views of both whites and blacks may reflect what has been termed the 'fundamental attribution error.' Experimentally controlled studies of the attribution process routinely find that observers systematically overestimate the extent to which an actor's behavior is attributable to internal causes and systematically underestimate the importance of external causes. This tendency to over attribute to internal causes and to be especially likely when judging a disliked out-group. ... ${ }^{12}$ This general psychological bias toward dispositional attributions when joined with possible self-interest motivations to protect a historically privileged group status may reflect a reasoned opposition of some whites to black advancement. ${ }^{13}$

When observing factors in relation to their means in descending order, the range for factors related to professional advancement is from abilities or perceived events that are considered to be in a person's control (internal) to events that individuals have little control over (external) (see table 5). For example, communication skills and organizational skills are abilities a person has some control over. However, factors such as whether one has a mentor or whether one can develop political connections are not in one's own control. For instance, Herbert Lefcourt notes:

... perceived control is referred to as a generalized expectancy of internal or external control of reinforcement. The formal terms, the generalized expectancy of internal control refers to the perception of events, whether positive or nega- 


\section{TABLE 5}

Problem Factors in Descending Order by Mean

Factors

Means

Old Boy Network, Non-Black Academic

Selection Process, Public and Other

Selection Process, Non-Black Academic

Stereotyped Race, Public and Other

Old Boy Network, Public and Other

Credibility, Non-Black Academic

Credibility, Public and Other

Selection Process, His. Black Academic

Lack of Role Models, Public and Other

Stereotyped Race, Non-Black Academic

Competent Administrator, Public and Other

Stereotyped Race, His. Black Academic

Competent Administrator, Non-Black Academic

Competent Administrator, His. Black Academic

Old Boy Network, His. Black Academic

Lack of Role Models, His. Black Academic

Lack of Role Models Non-Black Academic

tive, as being a consequence of one's own actions and thereby potentially under personal control. The generalized expectancy of external control, on the other hand, refers to the perception of positive or negative events as being unrelated to one's own behavior and therefore beyond personal control. ${ }^{14}$

When the same observation is made of factors that are problems for respondents the same phenomenon is observed. The relationship is the inverse of those related to professional growth. These factors range from events that are not in a person's control to those that a person does have some control over. This phenomenon is referred to in the discipline of social psychology as the psychology of control. Scales have been developed to ascertain the degree to which people perceive control over events in their lives. This area in social psychology is called the "locus of control." It originally consisted of two main areas of control: internal (person feels control of events) and external (person feels no control over events). The literature in this area asserts that many minorities feel that many events in their lives are in the control of powerful others or are external. ${ }^{15-18} \mathrm{Per}-$ ceived control, according to Lefcourt, is associated with access to opportunity. Persons who are able, through position and group membership, to attain more readily the valued outcomes that allow them to feel personal satisfaction are more likely 
to hold internal control expectancies. Minority groups, such as African Americans, Hispanic Americans, and Native Americans, who do not enjoy as much access to opportunity as do the predominant Caucasian groups in American society often feel in less control of events in their lives. ${ }^{19}$

Factors rated by the respondents as causing problems for them are factors that are also documented in the literature as being problems for minorities. In 1990, Jaynes and Williams reported that the quality of employment African Americans obtain is correlated with the racial composition of their social networks. Not being accepted into the old boy network leads to poor-paying jobs, and integrated networks lead to better-paying, less segregated work. ${ }^{20}$ Stereotypes, according to

Factors rated by the respondents as causing problems for them are also documented in the literature as being problems for minorities.

Richard Lippa, unjustly portray outgroups more negatively than they portray in-groups, exaggerate group differences, and lead to unjust underestimates of the variability of people within other groups. Ethnocentrism, the belief that one's own group is superior to other groups, is frequently the root of such stereotypes. ${ }^{21}$ When factors are observed by mean in descending order by type of institution, the same pattern is prevalent. The factors range from factors in one's control to those that are not in one's control. Table 5 lists problem factors in descending order. When factors are listed in descending order it appears that administrators at historically Black academic institutions have fewer problems than those at public or non-Black academic institutions. Doris Price, in her study "The Academic Environment As Perceived by Professional Black Personnel in Predominantly White Institutions," found that African Ameri- cans at predominantly White institutions had perceptions of isolation and alienation. ${ }^{22}$ Therefore, African American library administrators at public and nonBlack academic settings have perceptions that are consistent with this finding.

\section{Summary}

Evidence found from this study can be used to provide a basic profile of African American male library administrators. The study also provides basic demographic information that characterizes this minority in the profession. It chronicles the career paths to current positions for these administrators. The study explores the decision to become a librarian and the factors that influenced the decision. Finally, it gives this minority the opportunity to document its perceptions of opportunities for African American males in the profession.

Race relations and opportunities for African Americans and other minorities in the United States have greatly improved. However, many of the respondents identified race as a factor continuing to hinder professional advancement. In their comments, many of the respondents also made reference to racism as a problem when asked to rate factors that may have affected their professional advancement. The identification of racism as a problem by those who participated in the study is a manifestation of how pervasively racism affects these professionals. There is a need for more awareness of this problem. Therefore, there is a need for more programs to ensure equal opportunity for all African American males because they represent a distinct minority within the profession. These fifty-five African American librarians represent the gender that occupies the most prestigious positions within the profession. However, they also represent a racial minority of an underrepresented group in the profession. There are characteristics that are unique to this minority in the profession. This study makes a 
beginning attempt at identifying some of the distinctive career patterns, demographic characteristics, and perceptions. Additional studies should focus on this group and other racial minorities within the profession.

In the early 1970 s, the recruitment and retention of minorities in the profession of librarianship was a top priority. However, this is no longer the case, as other issues have taken higher priority. ${ }^{23}$ This state of affairs is serious in light of the changing demographics of the United States. By the year 2000, more than onethird of the U.S. population will be people of color. These changing demographics of America warrant that recruitment and retention of people of color in all professions, including librarianship, be a top priority.

Earlier efforts in the recruitment of minorities made by ALA have obviously not succeeded. Efforts, such as ALA's program of Each One Reach One, have resulted in only minuscule increases in minority recruitment to the profession. ${ }^{24}$ Facilitating recruitment of qualified $\mathrm{mi}-$ norities to the profession will take a concerted effort by all elements within the profession working together with ALA, the library and information science schools, and the libraries of the nation.

\section{Notes}

1. Stanley D. Eitzen, In Conflict and Order: Understanding Society (Boston: Allyn and Bacon, 1988), 20.

2. Ibid., 589.

3. Ibid., 100.

4. David Gerald Jaynes and Robin M. Williams Jr., A Common Destiny: Blacks and American Society (Washington, D.C.: National Academy Pr., 1989), 47.

5. E. J. Josey and Ann Allen Shockley, comps., A Handbook of Black Librarianship (Littleton, Colo.: Librarians Unlimited, 1977), 15-24.

6. American Library Association, American Library Directory 1990-1991, 43rd ed., vol. 2 (New Providence, N.J.: ALA, 1990).

7. American Library Association, American Library Directory 1991-1992, 44th ed. vol. 2 (New Providence, N.J.: ALA, 1991).

8. George C. Grant, comp. The Directory of Ethnic Professionals in LIS (Winter Park, Fla.: FourG Publishers, 1991).

9. ALA Black Caucus, Membership Directory of the Black Caucus of the American Librarian Association, 7th ed. (Chicago: Black Caucus of ALA, 1991).

10. ALA Black Caucus, Membership Directory of the Black Caucus of the American Librarian Association, 6th ed. (Chicago: Black Caucus of ALA, 1990).

11. Merriam-Webster Dictionary, 3rd ed., s.v. "problem."

12. Jaynes and Williams, A Common Destiny, 47.

13. Ibid., 154.

14. Herbert M. Lefcourt, Locus of Control: Current Trends in Theory and Research (Hillsdale, N.J.: Erlbaum Assoc., 1982), 35.

15. Ibid., 1-18.

16. Claudia Garcia and Hanna Levenson, 'Differences between Blacks' and Whites' Expectations of Locus of Control," Psychology Reports 37 (1975): 563-66.

17. Richard Lippa, Introduction to Social Psychology (Belmont, Calif.: Wadsworth, 1990).

18. Patricia Gurin, Gerald Gurin, Rosina C. Lao, and Muriel Beattie, "Internal-External Control in the Motivated Dynamics of Negro Youth," Journal of Social Issues 25, no. 3 (1969): 29-53.

19. Lefcourt, Locus of Control, 35.

20. Jaynes and Williams, A Common Destiny, 321.

21. Lippa, Introduction, 310.

22. Doris Price, "The Academic Environment As Perceived by Professional Black Personnel in Predominantly White Institutions" (Ph.D. diss., Texas Southern University, 1988), microfiche.

23. Cliff Glaviano and Errol R. Lam, "Academic Libraries and Affirmative Action: Approaching Cultural Diversity in the 1990's," College \& Research Libraries 51 (1990): 513-23.

24. Ibid. 


\section{Recommended Titles for the Academic Library}

THE HUMANITIES: A Selective Guide to Information Sources 4th Edition

Ron Blazek and Elizabeth Aversa

Higbly recommended for public and academic libraries-Reference Books Bulletin

Recommended for all libraries.-Choice

Includes approximately 1,250 main entries, with many additions to all sections-general humanities, philosophy, religion, visual arts, performing arts, and language and literature.

Library Science Text Series

1994 xix, 504p.

clotb ISBN 1-56308-167.9 $\$ 45.00$

paper ISBN 1-56308-168-7 \$35.00

\section{THE HUMANITIES CD:}

An Electronic Guide to Information Sources

Expanded coverage and increased access! The CD-ROM version covers 250 works not found in the print version and provides a detailed guide to nearly 1,500 information sources.

1995 CD-ROM ISBN 1-56308.361.2

$\$ 95.00$ per user

CLASSICAL STUDIES: A Guide to the Reference Literature

Fred W. Jenkins

A guide to bibliographical and information resources in all areas of classical studies, this book covers Greek and Latin languages and literatures, Greek and Roman history, and classical archeologies.

Reference Sources in the Humanities Series; James Rettig, Ed.

Winter 1996 ca.275p. ISBN 1-56308-110-5

$\$ 43.00$

\section{CONTEMPORARY RELIGIOUS} IDEAS: Bibliographic Essays

Edited by G. Edward Lundin and Anne H. Lundin

An enlightening overview of organized religion and spirituality today, this collection covers a spectrum of topics-from the African American Church and ecology and religious responsibility to Judaism, Islam, and world religions.

Winter 1996 ca.600p. ISBN 0.87287-679.9 $\$ 75.00$

VISUAL RESOURCES DIRECTORY: . Art Slide and Photograph

Collections in the United States and Canada

Visual Resources Association Carla Conrad Freeman, Editor Barbara Stevenson, Canadian Editor

More than 500 visual collectionsin the areas of art, architecture, and design throughout the United States and Canada are covered in this comprehensive directory. Listings provide complete information, from name and title of an individual in charge to hours, size of collection and staff, and visual formats collected.

1995 xvii, 174p. 81/2x11 paper ISBN 1.56308-196.2 \$45.00

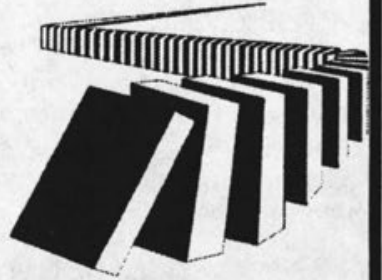

\section{from LIBRARIES UNLIMITED}

In order contact Libraries L nlimited. Dept. A6-

PO Box 6633 Englewood ( O $8015 ;-6633$

Phone: $1-83(1)-23--6,12+$ fax: $1-303-220-88+3$ I-mail dilulu.com 